\title{
A novel electrochemical sensor based on metal nanoparticles and molecularly imprinted polymer nanocomposite with biological applications
}

Rudarsko-geološko-naftni zbornik

(The Mining-Geology-Petroleum Engineering Bulletin) UDC: $622: 669$

DOI: $10.17794 / \operatorname{rgn} .2022 .1 .7$

Original scientific paper

\author{
Farzaneh Shaker'; Mohammad Taghi Vardini' ${ }^{1}$ Moosa Es'haghi'; Ebrahim Ghorbani Kalhor ${ }^{1}$ \\ ${ }^{1}$ Department of Chemistry, Tabriz Branch, Islamic Azad University, Tabriz, Iran.
}

\begin{abstract}
Metal nanoparticles trapped in a biopolymer composite due to electrical conductivity properties improve electrochemical sensors with biomedical and environmental applications. The study aims are to design a novel molecularly imprinted polymer (MIP) composite based on magnetic graphene oxide $\left(\mathrm{Fe}_{3} \mathrm{O}_{4} \rightarrow \mathrm{GO}\right)$ modified silica $\left(\mathrm{SiO}_{2}\right)$ and gold nanoparticles (AuNPs) to electrochemically detect serotonin (5-hydroxytryptamine, 5-HT). A suitable amount of 5 -HT is effective on motivational functions and the environment because it is a serotonergic neurotransmitter. However, the desired nanocomposite may have a relatively low recognition, therefore the type of functional monomer must be carefully chosen. In this regard, the design of the electrochemical sensor began with the synthesis of $\mathrm{Fe}_{3} \mathrm{O}_{4} \rightarrow \mathrm{GO}-\mathrm{SiO}_{2} \rightarrow$ AuNPs nanocomposite. Then, MIP electropolymerization was carried out by using p-aminothiophenol (PATP)-functionalized $\mathrm{Fe}_{3} \mathrm{O}_{4} \rightarrow \mathrm{GO}^{3}$ $\mathrm{SiO}_{2} \rightarrow$ AuNPs nanocomposite in the presence of ${ }_{5} \mathrm{HT}$ as a template molecule. Electrochemical polymerization of MIP nanocomposite was developed using cyclic voltammetry (CV) and the electrochemical properties of 5 -HT were studied with the use of differential pulse voltammetry (DPV) technology in the ${ }_{5} \mathrm{HT}$ solution. After optimization of preparation and measurement conditions on the designed sensor, the ${ }_{5} \mathrm{HT}$ concentration range was $0.1 \mu \mathrm{M}$ to $10 \mu \mathrm{M}$ linearly, and the detection limit was $1 \times 10^{-5} \mu \mathrm{M}(\mathrm{S} / \mathrm{N}=3)$. The wide concentration range and low detection limit presented with metal nanoparticles functionalized MIP with the appropriate functional monomer have a great effect on the performance of the sensor. Furthermore, PATP-functionalized metal nanoparticles increase the conductivity and recognition of the prepared MIP electrochemical sensor to the quantification of 5-HT in biological samples with high selectivity and recovery.
\end{abstract}

\section{Keywords:}

electrochemical sensor; metal nanoparticles; molecularly imprinted polymer; p-aminothiophenol

\section{Introduction}

Electrochemical sensors based on metal nanoparticles and MIP composite are used in medical, pharmaceutical, agricultural, and environmental areas (Parnianchi et al., 2018). Metal nanoparticles are mine productions such as iron and gold deposits that, after extraction and separation, are used broadly in electrochemical sensors for 5-HT detection in human blood and urine samples (Gholamnejad et al., 2020). One of the most wellknown neurotransmitters is 5-HT in serotonergic neurons and the effects on the growth and proliferation of brain neurons (Wu et al., 2019). Although 5-HT was discovered over 60 years ago, the study of 5-HT and its receptors continues to yield new biological information about the central nervous system (Berger et al., 2009). The serotonergic system is vital in the regulation of virtually all brain functions, and dysregulation of the serotonergic system is associated with the pathogenesis of many psychiatric and neurological disorders (Murphy et al., 2006). Also, the 5-HT syndrome due to drug interactions is very familiar with mild symptoms of life-

Corresponding author: Mohammad Taghi Vardini mtvardini@iaut.ac.ir threatening, habits of living, and destructive biochemical effects on the environment (Volpi-Abadie et al., 2013). Therefore, accurate determination of 5-HT is vital for the diagnosis of various mental diseases.

Different analytical methods in this field have focused on 5-HT detection, including high-performance liquid chromatography (HPLC) (Chau., Patel, 2009), fluorescence (Hernández-Mendoza et al., 2020), chemiluminescence (Kong et al., 2021), and capillary-electrophoresis (Roychoudhury et al., 2020). However, all these methods involve some disadvantages, such as the use of a large volume of solvents incompatible with the environment, long working time, expensive devices, and complicated experimental processes. These disadvantages make it difficult to use these methods. Therefore, electrochemical sensors have become the most preferred method for detecting 5-HT, due to their prominent advantages, such as rapidness, low cost, facile operation (Zhong et al., 2020), time-saving, and easy miniaturization (Li et al., 2016).

The technology of MIP is a powerful tool in the composite structure that makes electrochemical sensors the preferred method of 5-HT determination over other analytical methods. Good selectivity and stability with a view 
to mechanical, thermal, and chemical stability is the main characteristic in MIP-based electrochemical sensors (Sharma., Kandasubramanian, 2020), although the use of MIP due to long response times, low electrocatalytic, and poor adhesion is limited. To improve the adhesion of analytical methods based on MIP, some modifiers have been investigated (Lowdon et al., 2020). Among these factors, graphene has excellent applications for modifying electrodes (Yáñez-Sedeño et al., 2017). Due to its many remarkable properties, such as high mechanical strength and electrical conductivity, graphene has been employed widely in electrochemical sensors based on MIP nanocomposite (El-Maraghy et al., 2020). Graphene has a honeycomb structure and sheets are composed of carbon atoms (Ioniţă et al., 2017). Graphene oxide (GO) is made from the oxidation of graphite in the form of multiple stacked layers in protonated solvents (Qian et al., 2020). Oxidized graphene has hydroxyl $(-\mathrm{OH})$, alkoxy $(\mathrm{C}-\mathrm{O}-$ $\mathrm{C})$, carbonyl $(\mathrm{C}=\mathrm{O})$, carboxylic $(-\mathrm{COOH})$, and other oxygen-based functional groups (Smith et al., 2019). However, graphene alone cannot improve the adhesion of electrochemical sensors and we don't know what substance we could use in its place.

Therefore, after studying we found metal nanomaterials with specific catalytic activity and appropriate functional monomers can be used for sensing applications of MIP graphene composite, but in the following section we will discuss the effectiveness of modified MIP composite electrochemical sensors. Metal nanoparticles besides graphene in MIP composite give many advantages, such as excellent electrical conductivity (Baig et al., 2019), catalytic effect (Torri et al., 2010) favorable engineering properties, low toxicity, cost-effectiveness (Santos et al., 2009), high sensitivity, selectivity, mechanical, chemical, and thermal stability (He et al., 2019). Magnetic nanoparticles are used as the most important metal nanoparticles due to their biocompatibility, non-toxicity, catalytic activity, and high surface area. Magnetic graphene oxide $\left(\mathrm{Fe}_{3} \mathrm{O}_{4} \rightarrow \mathrm{GO}\right)$ is a good analytical choice because large additional GO surfaces have been developed to hybridize with $\mathrm{Fe}_{3} \mathrm{O}_{4}$ nanoparticles (Afzali et al., 2020). Silica is a great modifying agent in electrochemical sensors due to enhancing stability, reducing the toxic effects of magnetic nanoparticles, and lowering aggregation (Wondracek et al., 2016). Gold nanoparticles doped with $\mathrm{Fe}_{3} \mathrm{O}_{4} \rightarrow \mathrm{GO}-\mathrm{SiO}_{2}$ composite matrix enhance the conductivity and the electron transfer rate (Lu et al., 2009). The nanocomposite of $\mathrm{Fe}_{3} \mathrm{O}_{4} \rightarrow \mathrm{GO}_{-} \mathrm{SiO}_{2} \rightarrow$ AuNPs in MIP electropolymerization can dope with PATP and PATP due to its unique properties and protect the designed nanocomposite against corrosion while increasing conductivity and recognition. So, MIP electrochemical sensors based on $\mathrm{Fe}_{3} \mathrm{O}_{4} \rightarrow \mathrm{GO}-\mathrm{SiO}_{2} \rightarrow$ AuNPs are performed by three electrodes for detecting biological molecules, as well as drugs. A carbon paste electrode (CPE) modified by metal nanomaterials and MIP composite is used as the working electrode, platinum is employed as the auxiliary electrode, and $\mathrm{Ag} / \mathrm{AgCl}, \mathrm{KCl}$ is used as the reference electrode (Khalifa et al., 2020).

Researchers such as Battistelli et al. prepared a composite of thermoplastic starch (TPS) based iron particles that the conductivity of composite increased by the dispersion of iron filings on the surface of the composite (Battistelli et al., 2020). Also, Karavasilis and Tsakiroglou synthesized aqueous suspensions of zero-valent iron nanoparticles (nZVI) by mixing a plant extract solution with an aqueous solution of iron sulfate heptahydrate $\left(\mathrm{FeSO}_{4} \cdot 7 \mathrm{H}_{2} \mathrm{O}\right)$ (Karavasilis., Tsakiroglou, 2019). A composite of MIP modified multi-walled carbon nanotubes (MWCNTs), ionic liquid and platinum (Pt) nanoparticles was prepared by Zhao et al (Zhao et al., 2014). In all these studies, the conductivity and recognition elements of these composites modified metal particles are low because of the lack of a suitable functional monomer in the polymeric composite.

In the current work, a new nanocomposite was designed to determine 5-HT by combining functionalized GO and MIP in real samples. First, GO from graphite was synthesized. Next, the surface of GO by employing magnetic nanoparticles was modified to separate nanocomposites easily from the reaction mixture. Then $\mathrm{Fe}_{3} \mathrm{O}_{4} \rightarrow \mathrm{GO}-\mathrm{SiO}_{2}$ was produced from the binding of (3-mercaptopropyl) trimethoxysilane (MPS) on $\mathrm{Fe}_{3} \mathrm{O}_{4} \rightarrow \mathrm{GO}$. The surface functional groups of GO could couple with silane agents. Nanoparticles of gold were dropped on the $\mathrm{Fe}_{3} \mathrm{O}_{4} \rightarrow \mathrm{GO}-\mathrm{SiO}_{2}$ to increase the electron transfer between the sensor elements and the MIP. The combination of AuNPs and S of MPS was suitable for MIP synthesis in the presence of 5-HT. The work herein presents a biometric sensor based on MIP for the detection of 5-HT. The potentiodynamic electropolymerization using a solution containing PATP in the presence of 5-HT as a template molecule was carried out. The functional monomer of PATP was first self-assembled on the surface of CPE. The electropolymerization occurred by $\mathrm{CV}$ in a solution containing PATP and 5-HT. The removal of 5-HT from the resulted polymer matrix leads to selective recognition cavities that can bind the analyte from sample solutions. Techniques of SEM and FT-IR were employed for checking the morphology of the $\mathrm{Fe}_{3} \mathrm{O}_{4} \rightarrow \mathrm{GO}_{-} \mathrm{SiO}_{2} \rightarrow \mathrm{AuNPs} \rightarrow \mathrm{MIP}$ nanocomposite. The electrochemical behavior of the designed sensor was studied by CV, DPV, and electrochemical impedance spectroscopy (EIS). As far as the author knows, this is the first time that the electropolymerized MIP electrochemical sensor-based $\mathrm{Fe}_{3} \mathrm{O}_{4} \rightarrow \mathrm{GO}-\mathrm{SiO}_{2} \rightarrow$ AuNPs and PATP have been used to electrochemically measure 5HT in real biological samples with a high recovery rate.

\section{Materials and Methods}

\subsection{Chemicals}

Pure graphite powder, 5-HT, PATP, and MPS (purity 99\%) were purchased from Sigma Aldrich Co. (St. Louis, MO, USA). Hydrochloric acid $(\mathrm{HCl})$, concentrated 


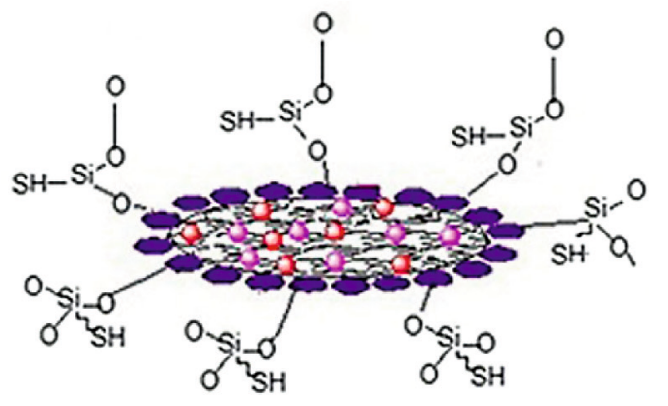

Remove of 5.HT

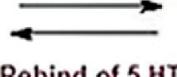

Rebind of $5 . \mathrm{HT}$

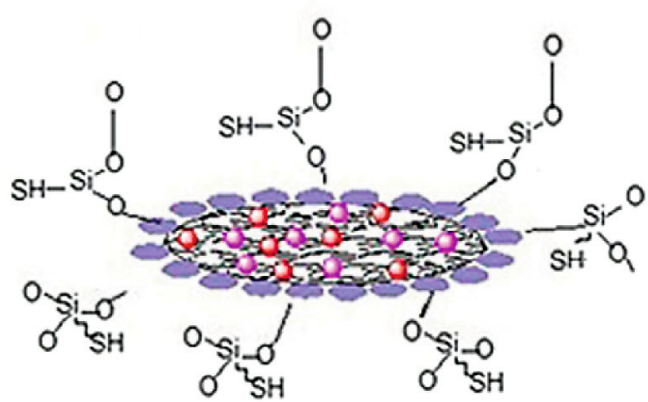

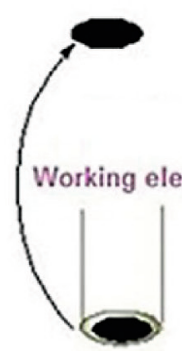

\section{Electrochemical polymerization}

$5.0 \times 10^{-2} \mathrm{M}$ PATP in the presence of $1.0 \times 10^{-4}$ M 5-HT and supporting electrolyte of $0.1 \mathrm{M}$ $\mathrm{KNO}_{3}$ in methanol containing $1.0 \times 10^{-2} \mathrm{M} \mathrm{HCl}$ $(\mathrm{pH} 7.0)$
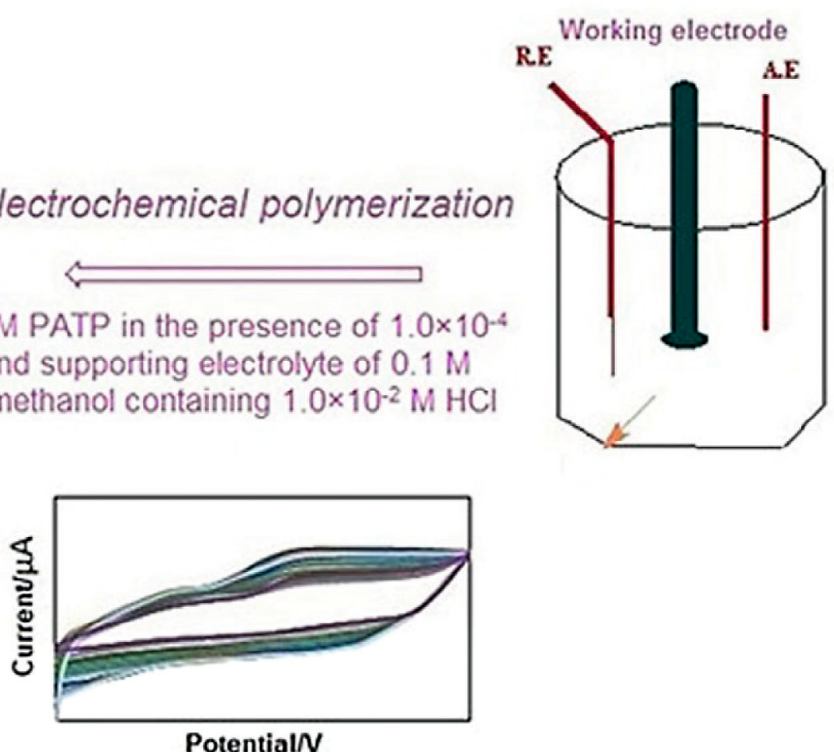

Figure 1: Preparation of electrochemical sensor based on MIP electropolymerized schematically (synthesis of MIP modified nanocomposite on CPE as a working electrode by electrochemical polymerization)

sulfuric acid $\left(\mathrm{H}_{2} \mathrm{SO}_{4}\right)$, sodium nitrate $\left(\mathrm{NaNO}_{3}\right)$, potassium permanganate $\left(\mathrm{KMnO}_{4}\right)$, hydrogen peroxide $\left(\mathrm{H}_{2} \mathrm{O}_{2}\right)$, iron (II) chloride $\left(\mathrm{FeCl}_{2}\right)$, iron (III) chloride $\left(\mathrm{FeCl}_{3}\right)$, chloroauric acid $\left(\mathrm{HAuCl}_{4}\right)$, trisodium citrate, acetonitrile, toluene, methanol for the preparation of a standard solution of 5-HT, $30 \%$ ammonia, lithium chloride $(\mathrm{LiCl})$, potassium nitrate $\left(\mathrm{KNO}_{3}\right)$, potassium chloride $(\mathrm{KCl})$, sodium chloride $(\mathrm{NaCl})$, potassium hydroxide $(\mathrm{KOH})$, barium hydroxide $\mathrm{Ba}(\mathrm{OH})_{2}$, zinc sulfate $\left(\mathrm{ZnSO}_{4}\right)$ and paraffin wax were all obtained from Merck (Germany). All the chemicals were used without purification and all the solutions were prepared with double ionized distilled water.

\subsection{Electrochemical and surface test methods}

A Scanning Electron Microscope (SEM) (High magnifier and accuracy of measurement: $\mu \mathrm{m})$ and FT-IR spectra (wavenumber range 400 to $4000 \mathrm{~cm}^{-1}$ ) were used to study all nanocomposite materials. The electrochemical measurement was performed on Autolab PGSTAT302N (Netherlands). The EIS measures the electrical resistance (impedance) of the $\left[\mathrm{Fe}(\mathrm{CN})_{6}^{-3 / 4}\right]$ solution over a wide frequency range $(0.1$ to $10000 \mathrm{~Hz}$; signal amplitude: $0.01 \mathrm{~V}$ ). The electrochemical system contained three-electrodes: MIP/CPE as the working electrode, platinum as the counter electrode, and $\mathrm{Ag} / \mathrm{AgCl}$, $\mathrm{KCl}$ as the reference electrode.

\subsection{Synthesis of $\mathrm{Fe}_{3} \mathrm{O}_{4} \rightarrow \mathrm{GO}-\mathrm{SiO}_{2} \rightarrow \mathrm{AuNPS}$
nanocomposite}

Graphene Oxide (GO) was synthesized from pure and natural graphite powder using Hummer's method (Chen et al., 2013). Particles of $\mathrm{Fe}_{3} \mathrm{O}_{4} \rightarrow \mathrm{GO}$ are synthesized by chemical coprecipitations of $3.5 \mathrm{~g} \mathrm{FeCl}_{2}, 5 \mathrm{~g} \mathrm{FeCl}_{3}$, and $0.05 \mathrm{~g}$ of $\mathrm{GO}$ in $100 \mathrm{~mL}$ of distilled water under an $\mathrm{N}_{2}$ atmosphere. The magnetic suspension was obtained after ultrasonic stirring and increasing the temperature and $\mathrm{pH}$. The $\mathrm{Fe}_{3} \mathrm{O}_{4} \rightarrow \mathrm{GO}$ particles remained in a magnetic field until the supernatant was separated and heated at $60^{\circ} \mathrm{C}$ under vacuum.

The $\mathrm{Fe}_{3} \mathrm{O}_{4} \rightarrow \mathrm{GO}-\mathrm{SiO}_{2}$ composite was synthesized by dissolving $0.1 \mathrm{~g}$ of $\mathrm{Fe}_{3} \mathrm{O}_{4} \rightarrow \mathrm{GO}$ in $50 \mathrm{~mL}$ of toluene for an hour and adding $3 \mathrm{~mL}$ MPS. The solution was heated for 48 hours under an $\mathrm{N}_{2}$ atmosphere, resulting in a solid which was washed with toluene several times. The sedi- 


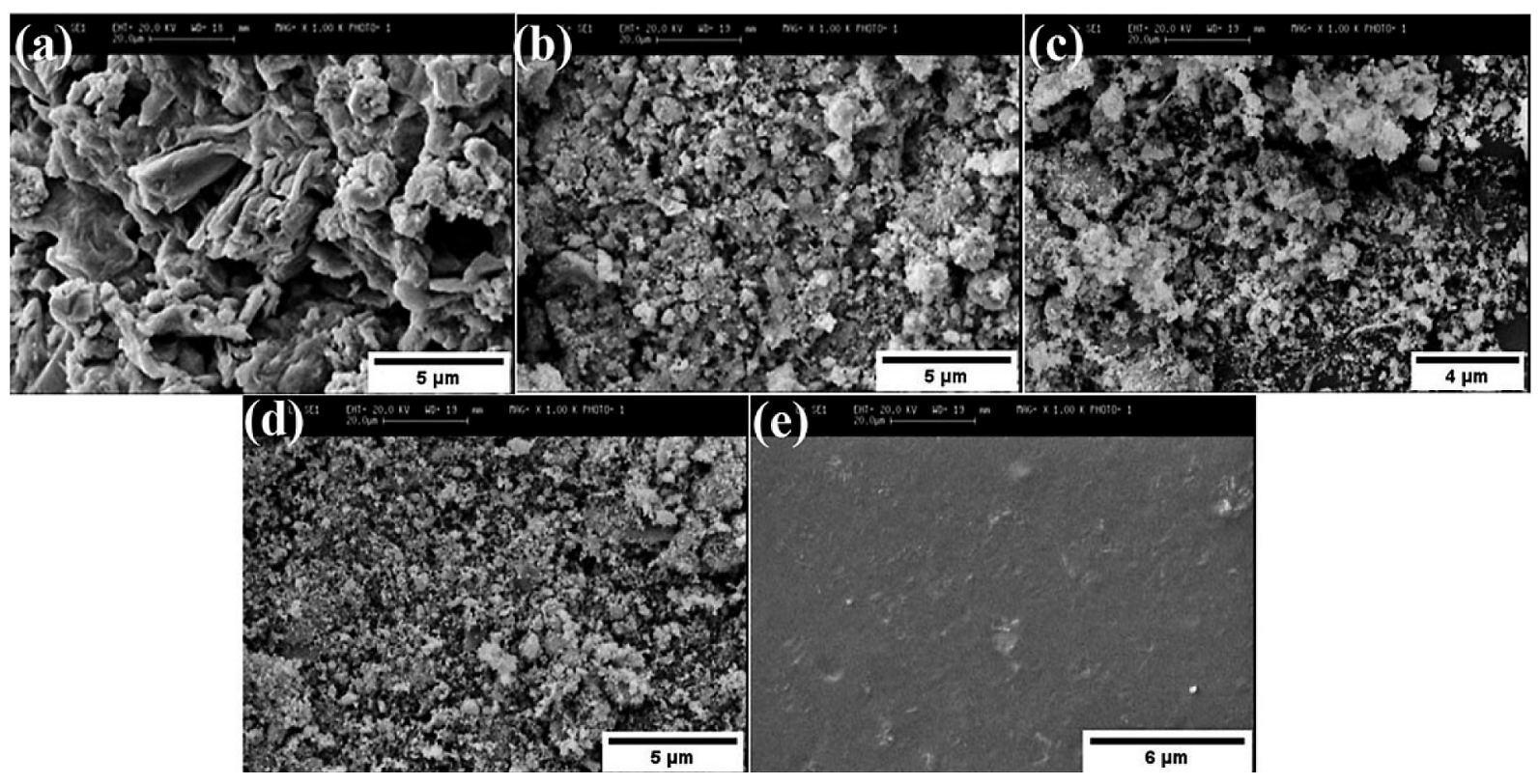

Figure 2: The SEM images of (a) GO, (b) $\mathrm{Fe}_{3} \mathrm{O}_{4} \rightarrow \mathrm{GO}$, (c) $\mathrm{Fe}_{3} \mathrm{O}_{4} \rightarrow \mathrm{GO}-\mathrm{SiO}_{2}$,

(d) $\mathrm{Fe}_{3} \mathrm{O}_{4} \rightarrow \mathrm{GO}-\mathrm{SiO}_{2} \rightarrow$ AuNPs, (e) $\mathrm{Fe}_{3} \mathrm{O}_{4} \rightarrow \mathrm{GO}-\mathrm{SiO}_{2} \rightarrow$ AuNPs $\rightarrow$ MIP for characterization of performance particles in the electrochemical sensor

ment was dried at $60^{\circ} \mathrm{C}$ in an oven to obtain salinization modification of $\mathrm{Fe}_{3} \mathrm{O}_{4} \rightarrow \mathrm{GO}$.

Generally, in this work, AuNPs were produced by a trisodium citrate reduction method with slight modification (Dong et al., 2010). Briefly, $3.65 \mathrm{~mL}$ of $0.1 \mathrm{M} \mathrm{HAu}-$ $\mathrm{Cl}_{4}$ solution was dissolved in $150 \mathrm{~mL}$ of double ionized distilled water and heated while stirring until boiling. Then, $3 \mathrm{~mL}$ of tri-sodium citrate $(1 \mathrm{wt} \%)$ was slowly added to the aqueous solution. Finally, when the color of the solution reached a red color, indicating the formation of AuNPs, heat was removed so that the solid particles were obtained at $4^{\circ} \mathrm{C}$. All of the $\mathrm{Fe}_{3} \mathrm{O}_{4} \rightarrow \mathrm{GO}-\mathrm{SiO}_{2}$ particles were added to $15 \mathrm{~mL}$ of the wine-red solution of AuNPs and stirred vigorously for 2 hours until the solution became colorless. The solid particles were separated in a magnetic field and dried in a vacuum at $60^{\circ} \mathrm{C}$. Eventually, $\mathrm{Fe}_{3} \mathrm{O}_{4} \rightarrow \mathrm{GO}-\mathrm{SiO}_{2} \rightarrow$ AuNPs were gained.

\subsection{Preparation of CPE and MIP electrochemical polymerization}

The CPE was applied to measure the analyte as a working electrode. Therefore, CPE was prepared from $0.04 \mathrm{~g}$ of the nanocomposite material, $0.1 \mathrm{~g}$ of pure graphite, and $0.06 \mathrm{~g}$ of paraffin compacted at the end of a tube with a diameter of $3 \mathrm{~mm}$. A copper wire with a length of $5 \mathrm{~cm}$ was plunged inside the electrode and kept for 12 hours at room temperature to dry. The end surface of the electrodes was polished using sandpaper. It was necessary to keep the prepared electrode within methanol $(\mathrm{pH}=1)$ as a preparation solution for an hour before use.

To obtain a polymer matrix with selective recognition cavities for 5-HT, the CPE waited in a $5.0 \times 10^{-2} \mathrm{M}$ PATP methanolic solution for 12 hours at $4^{\circ} \mathrm{C}$. After the self- assembly of PATP, electropolymerization of MIP continued in a mixing solution containing $5.0 \times 10^{-2} \mathrm{M}$ PATP, $1.0 \times 10^{-4} \mathrm{M} 5$-HT in the supporting electrolyte of $0.1 \mathrm{M}$ $\mathrm{KNO}_{3}$ and methanol containing $1.0 \times 10^{-2} \mathrm{M} \mathrm{HCl}$, by cycling the potential between $-2 \mathrm{~V}$ and $2 \mathrm{~V}$, for 50 cycles, with a scan rate of $0.1 \mathrm{~V} / \mathrm{s}$. To confirm the imprinting process, a control experiment with a non-imprinted polymer-modified electrode (NIP) was prepared under the same experimental conditions, but without the addition of 5-HT. The modified electrodes were put in a solvent of $\mathrm{HCl}$ : methanol $\mathrm{pH} 7.0$ (2:1) without the addition of 5-HT and PATP, by cycling the potential between $-2 \mathrm{~V}$ and $2 \mathrm{~V}$, for 50 cycles, with a scan rate of $0.1 \mathrm{~V} / \mathrm{s}$ after removing the template molecules. According to Figure $\mathbf{1}$, synthesis and preparation steps of the electrochemical sensor based on MIP electropolymerized was shown. This electrochemical sensor in the same method for the biological sample and heavy metal cations that are dissolved in water is prepared and used.

\section{Results and Discussion}

\subsection{Characterization}

The present study was performed to investigate the effect of metal nanoparticles trapped in a polymer matrix on the performance of an electrochemical sensor for 5-HT detection in biological samples. For this purpose, first, the morphology and structural properties of synthesized particles in the polymer matrix were studied by SEM images and FT-IR spectrums.

The morphology of $\mathrm{GO}, \mathrm{Fe}_{3} \mathrm{O}_{4} \rightarrow \mathrm{GO}, \mathrm{Fe}_{3} \mathrm{O}_{4} \rightarrow \mathrm{GO}-$ $\mathrm{SiO}_{2}, \quad \mathrm{Fe}_{3} \mathrm{O}_{4} \rightarrow \mathrm{GO}-\mathrm{SiO}_{2} \rightarrow \mathrm{AuNPs}$, and $\mathrm{Fe}_{3} \mathrm{O}_{4} \rightarrow \mathrm{GO}-$ $\mathrm{SiO}_{2} \rightarrow$ AuNPs $\rightarrow$ MIP was characterized by SEM imag- 

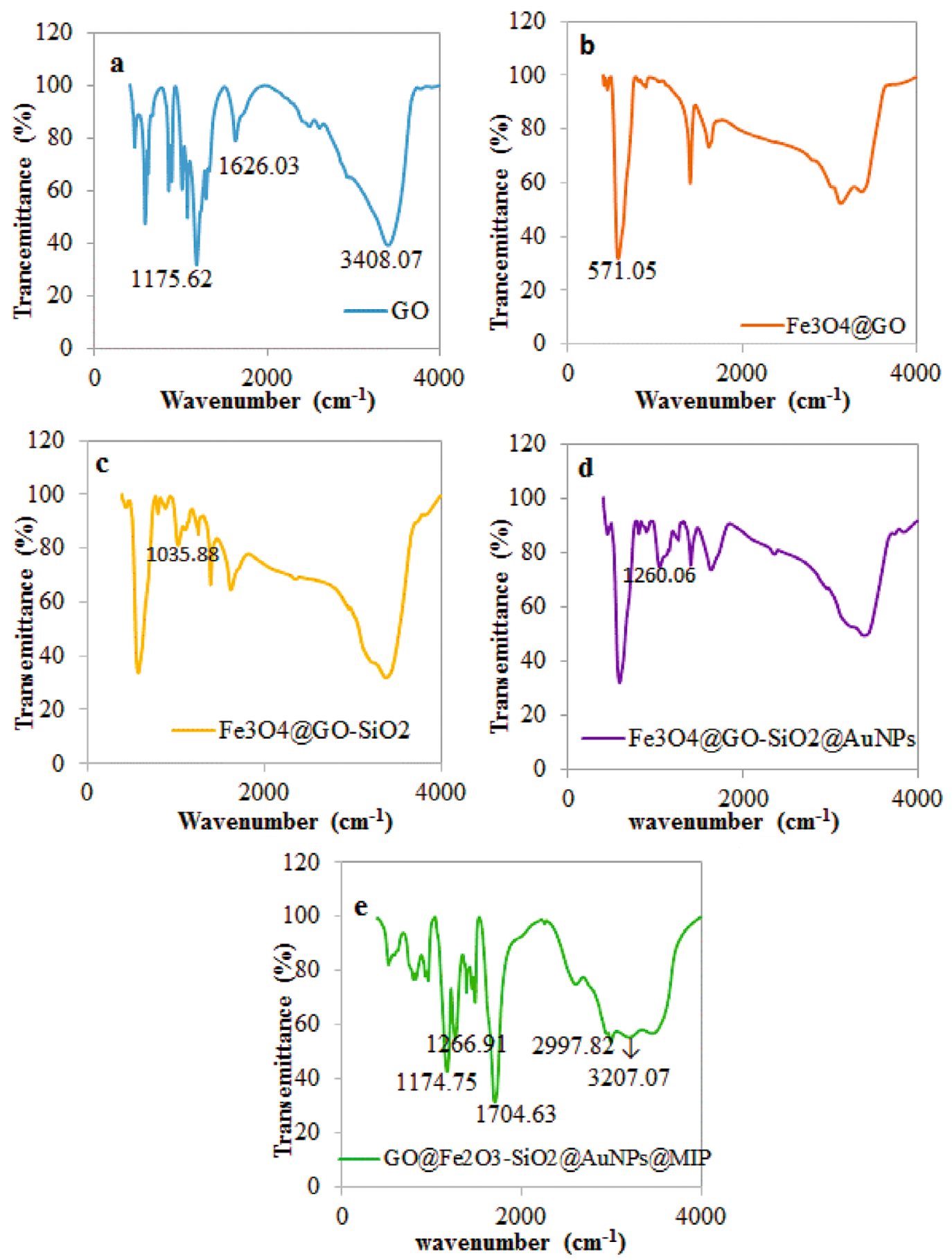

Figure 3: The FTIR spectra of (a) GO, (b) $\mathrm{Fe}_{3} \mathrm{O}_{4} \rightarrow \mathrm{GO}$, (c) $\mathrm{Fe}_{3} \mathrm{O}_{4} \rightarrow \mathrm{GO}_{-} \mathrm{SiO}_{2}$, (d) $\mathrm{Fe}_{3} \mathrm{O}_{4} \rightarrow \mathrm{GO}-\mathrm{SiO}_{2} \rightarrow \mathrm{AuNPs}_{\text {, }}$ (e) $\mathrm{Fe}_{3} \mathrm{O}_{4} \rightarrow \mathrm{GO}-\mathrm{SiO}_{2} \rightarrow \mathrm{AuNPs} \rightarrow \mathrm{MIP}$ for characterization of performance particles in the electrochemical sensor

es. According to Figure 2a GO has a sheet-like structure, smooth and thick surfaces with wrinkles. These wrinkles inhibit the aggregation of GO and increase the surface area. The $\mathrm{Fe}_{3} \mathrm{O}_{4}$ particles dispersed on the graphene plates according to Figure 2b. An aggregation formed between $\mathrm{GO}$ and iron particles compared to the previous stage. The surface of $\mathrm{Fe}_{3} \mathrm{O}_{4} \rightarrow \mathrm{GO}-\mathrm{SiO}_{2}$ particles according to Figure 2c showed tiny particles with highly uniform size and a spherical shape. A high density was observed in $\mathrm{Fe}_{3} \mathrm{O}_{4} \rightarrow \mathrm{GO}$ after modification with
MPS (see Figure 2c) that revealed oxidation and silanization of $\mathrm{Fe}_{3} \mathrm{O}_{4} \rightarrow$ GO. The synthesis of AuNPs in Figure 2d showed the surface composite that causes a composite with a high surface area compared to the previous stage. Polymeric composite according to Figure 2e displayed the smooth and homogeneous MIP film deposited over the CPE surface compared to the previous stage by applying electropolymerization in $5.0 \times 10^{-2} \mathrm{M}$ PATP solution containing $1 \times 10^{-4} \mathrm{M} 5$-HT. After reviewing these images and the results, it was found that metal nanopar- 

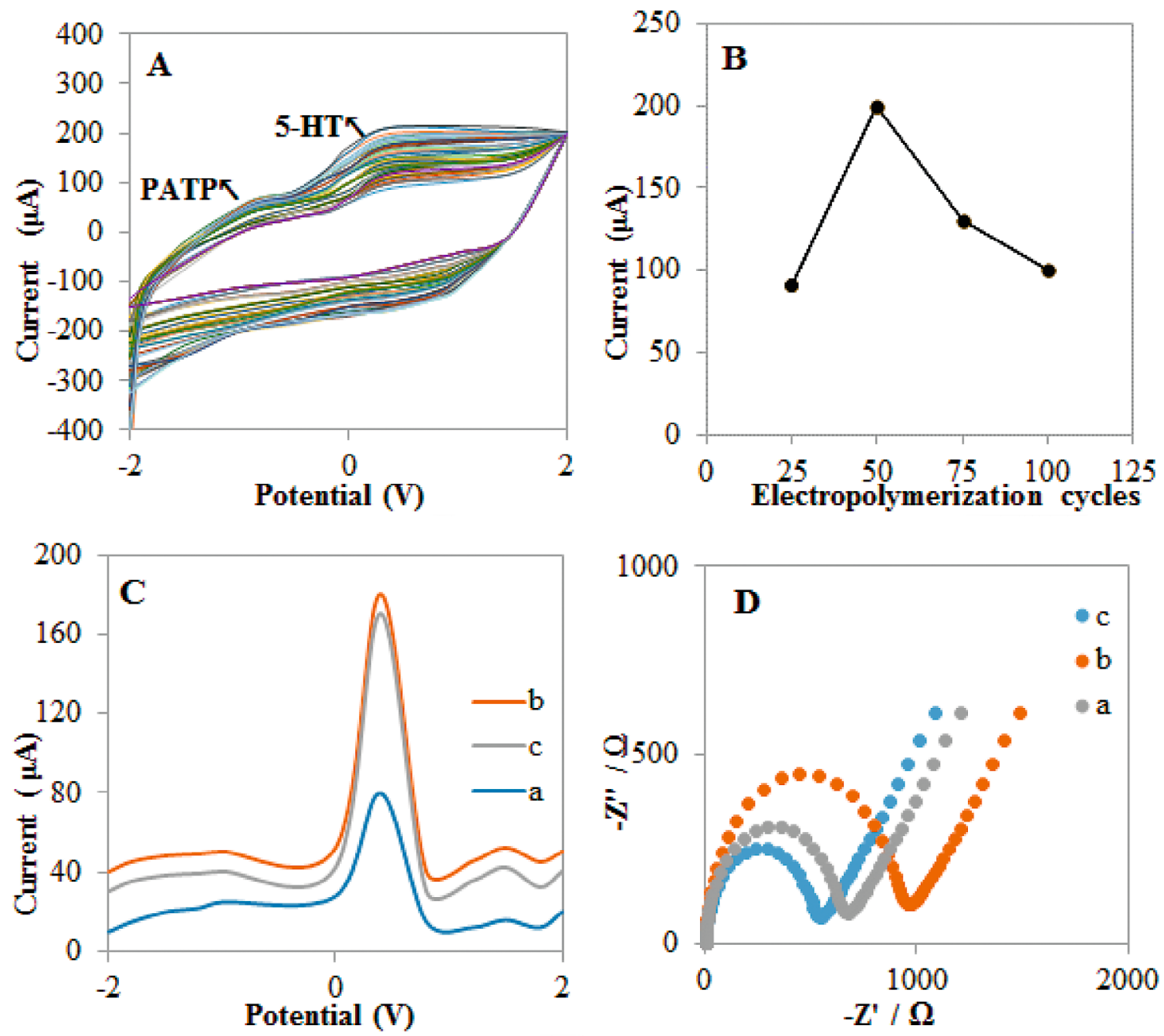

Figure 4: (A) Voltammetry cycles in solution of 5.0 $\times 10^{-2} \mathrm{M}$ PATP, $1.0 \times 10^{-4} 5-\mathrm{HT}$, and o.1 $\mathrm{M} \mathrm{KNO}_{3}(\mathrm{pH}$ 7.0) with 50 sequential cycles on the CPE for MIP electrochemical polymerization (scan rate $0.1 \mathrm{~V} / \mathrm{s}$ ) (B) The effect of electropolymerization cycles on the peak current of 5 -HT (C) The DPV responses on the (a) CPE, CPE/MIP, CPE/MIP after removal 5-HT in solution of $1 \times 10^{-4} \mathrm{M}^{2}$ and o.1 $\mathrm{M} \mathrm{KNO}_{3}(\mathrm{pH}$ 7.0) (scan rate o.1 V/s)

(D) Electrochemical impedance spectroscopy of $0.02 \mathrm{M}\left[\mathrm{Fe}(\mathrm{CN})_{6}\right]^{-3 /-4}$ on the electrode of (a) CPE (b) MIP/CPE

(c) MIP after removal of 5 - $\mathrm{HT}$ in solution of $1 \times 10^{-4} \mathrm{M}_{5}-\mathrm{HT}$ and o.1 $\mathrm{M} \mathrm{KNO}_{3}(\mathrm{pH} 7.0$ ) respectively (scan rate $0.1 \mathrm{~V} / \mathrm{s}$ )

ticles and MIP film were successfully synthesized on the composite. These results are consistent with previous reports in this field (Ghanbari.,Roushani, 2018), and with the formation of metal nanoparticles, the particle size is almost constant but with the formation of MIP film, particle size has somewhat increased, and thus the recognition of nanocomposite has increased.

The FT-IR spectrum, as shown in Figure 3, included $\mathrm{GO}, \quad \mathrm{Fe}_{3} \mathrm{O}_{4} \rightarrow \mathrm{GO}, \quad \mathrm{Fe}_{3} \mathrm{O}_{4} \rightarrow \mathrm{GO}-\mathrm{SiO}_{2}, \quad \mathrm{Fe}_{3} \mathrm{O}_{4} \rightarrow \mathrm{GO}-$ $\mathrm{SiO}_{2} \rightarrow$ AuNPs, and $\mathrm{Fe}_{3} \mathrm{O}_{4} \rightarrow \mathrm{GO}_{-} \mathrm{SiO}_{2} \rightarrow$ AuNPs $\rightarrow$ MIP. The FT-IR peak at $1175.62 \mathrm{~cm}^{-1}$ is related to the $\mathrm{C}-\mathrm{O}$ bond due to the oxidation of graphite. However, unoxidized graphite shows a peak at $1626.03 \mathrm{~cm}^{-1}$ related to the $\mathrm{C}=\mathrm{C}$ bond and water molecules contain hydroxyl groups of graphite rising to the absorption peak at $3408.07 \mathrm{~cm}^{-1}$ (curve a). The FT-IR peak at $571.05 \mathrm{~cm}^{-1}$ is related to the $\mathrm{Fe}-\mathrm{O}$ bond on the $\mathrm{Fe}_{3} \mathrm{O}_{4} \rightarrow \mathrm{GO}$ (curve b).
The FT-IR at $1035.88 \mathrm{~cm}^{-1}$ is related to the $\mathrm{Si}-\mathrm{O}-\mathrm{Si}$ bond on the $\mathrm{Fe}_{3} \mathrm{O}_{4} \rightarrow \mathrm{GO}-\mathrm{SiO}_{2}$, which vibrates asymmetrically (curve c). The FT-IR spectrum of $\mathrm{Fe}_{3} \mathrm{O}_{4} \rightarrow \mathrm{GO}$ $\mathrm{SiO}_{2} \rightarrow$ AuNPs was similar to the previous spectrum with the difference that a weak peak at $1260.06 \mathrm{~cm}^{-1}$ in silanized GO had low intensity. It was due to the connection of AuNPs to $\mathrm{S}$ on the $\mathrm{Fe}_{3} \mathrm{O}_{4} \rightarrow \mathrm{GO}$ surface through covalent bonding (curve d). Finally, the FT-IR spectrum of $\mathrm{Fe}_{3} \mathrm{O}_{4} \rightarrow \mathrm{GO}-\mathrm{SiO}_{2} \rightarrow$ AuNPs $\rightarrow$ MIP during the MIP synthesis on the surface of the functionalized CPE showed peaks at 1100 to $1300 \mathrm{~cm}^{-1}$, representing O-C-O and $\mathrm{C}-\mathrm{O}$ bonds, respectively. The carboxylic acid groups appeared as peaks at 2000 to $3000 \mathrm{~cm}^{-1}$ that related to the $\mathrm{C}-\mathrm{H}$ bond which vibrates symmetrically and asymmetrically. In this spectrum, a peak at $1704.63 \mathrm{~cm}^{-1}$, which covered all previous peaks, was related to the carbonyl group (curve e). Therefore, the FT-IR spectrums con- 

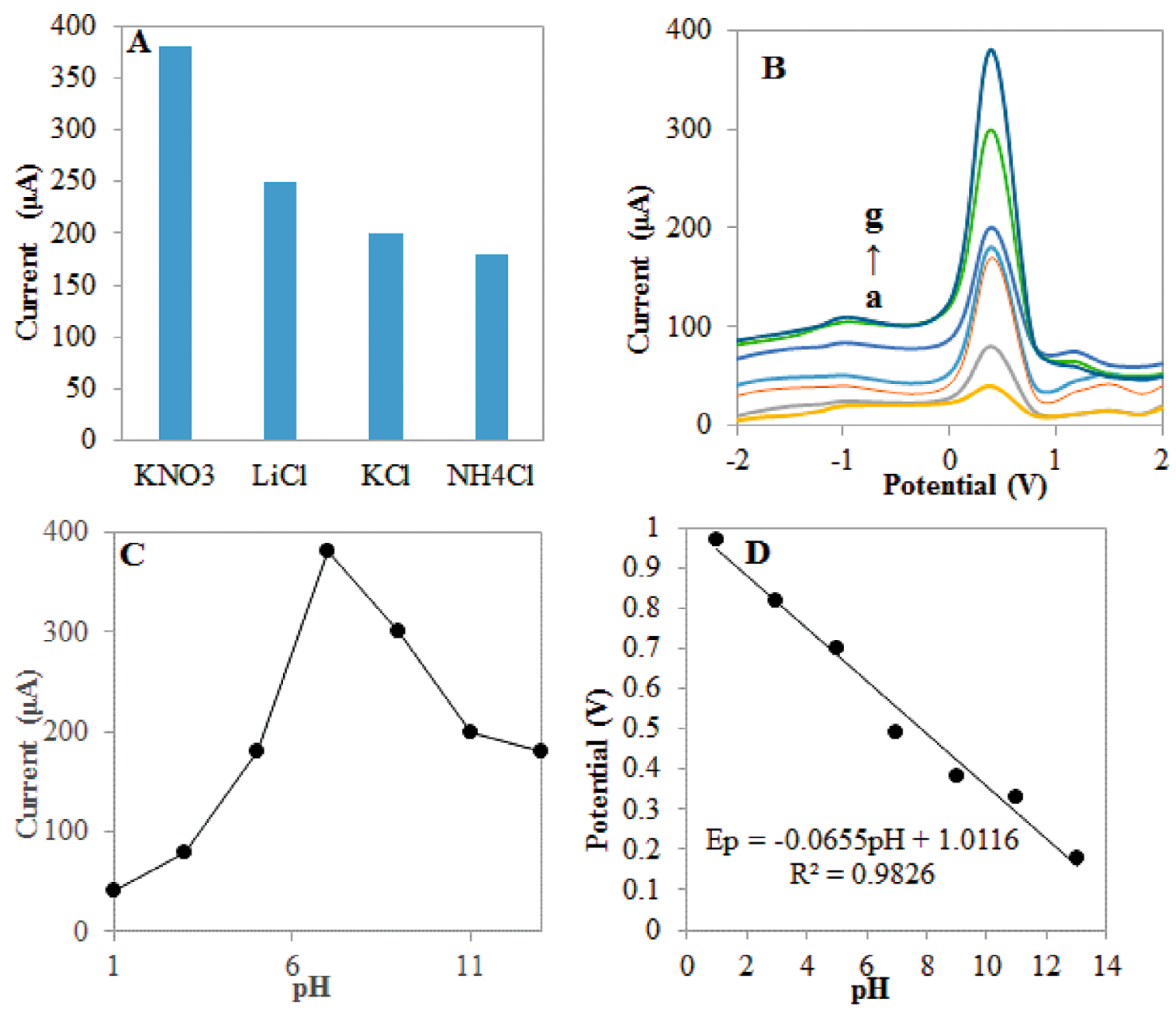

Figure 5: (A) Type of supporting electrolyte effective on 5-HT peak current

(B) The DPV responses of 5-HT on the MIP modified electrode in $0.1 \mathrm{M} \mathrm{KNO}_{3}$ containing $1.0 \times 10^{-4} \mathrm{M}_{5}$ - $\mathrm{HT}$, $\mathrm{pH}$ from 1.0 (curve a) to 13.0 (curve g) (C) Relationship between $\mathrm{pH}$ and 5-HT peak current in $0.1 \mathrm{M} \mathrm{KNO}_{3}$ containing $1.0 \times 10^{-4} \mathrm{M}_{5}-\mathrm{HT}, \mathrm{pH}$ from 1.0 to 13.0 (D)

firmed that $\mathrm{Fe}_{3} \mathrm{O}_{4}$ particles were cited on GO successfully and after being modified by other nanoparticles, MIP was successfully formed. Oxygen functional groups were reduced during MIP polymerization and according to previous studies (Ahmed et al., 2018) with the reduction of oxygen functional groups, the electrochemical response was enhanced.

\subsection{Electrochemical polymerization and properties of proposed electrode}

The cyclic voltammograms in Figure 4A show MIP electrochemical polymerization in the solution of $5.0 \times 10^{-2} \mathrm{M}$ PATP, $1.0 \times 10^{-4} \mathrm{M} 5-\mathrm{HT}$, and $0.1 \mathrm{M} \mathrm{KNO}_{3}$ as the supporting electrolyte in methanol containing $1.0 \times 10^{-2} \mathrm{M} \mathrm{HCl}(\mathrm{pH} 7.0)$ on the CPE. An anodic peak was observed at $-0.5 \mathrm{~V}$ due to the $\mathrm{OH}$ groups of PATP which reacted electrochemically on the surface electrode. Another anodic peak was observed at $0.4 \mathrm{~V}$, which should be related to the redox reaction of the catechol group on the 5-HT molecule (Gilbertson et al., 2018).
Increasing the number of scans led to an increase in peak intensity, which shows the formation of the PATP-based conducting polymer film. The results indicated that PATP and template molecules were successfully copolymerized on the CPE electrode surface by electrochemical polymerization. The number of scan cycles during electropolymerization affected the thickness of the MIP membrane. In this study, CV responses of different scan cycles were recorded in the number of 25 to 100 cycles, as shown in Figure 4B. High peak current was observed when the electropolymerization was performed by 50 $\mathrm{CV}$ scan cycles. Therefore, the number of scan cycles was accepted as 50 cycles for the electropolymerization.

The electrochemical properties of 5-HT were studied on the modified electrodes by DPV. As shown in Figure 4C, DPV measurements confirmed the current response of 5-HT on the MIP/CPE (curve b) is much higher than those on the CPE (curve a) and MIP/CPE after the removal of 5-HT (curve c), which could be related to excellent MIP detection ability towards the template molecules (Peeters et al., 2012). This result showed that the 

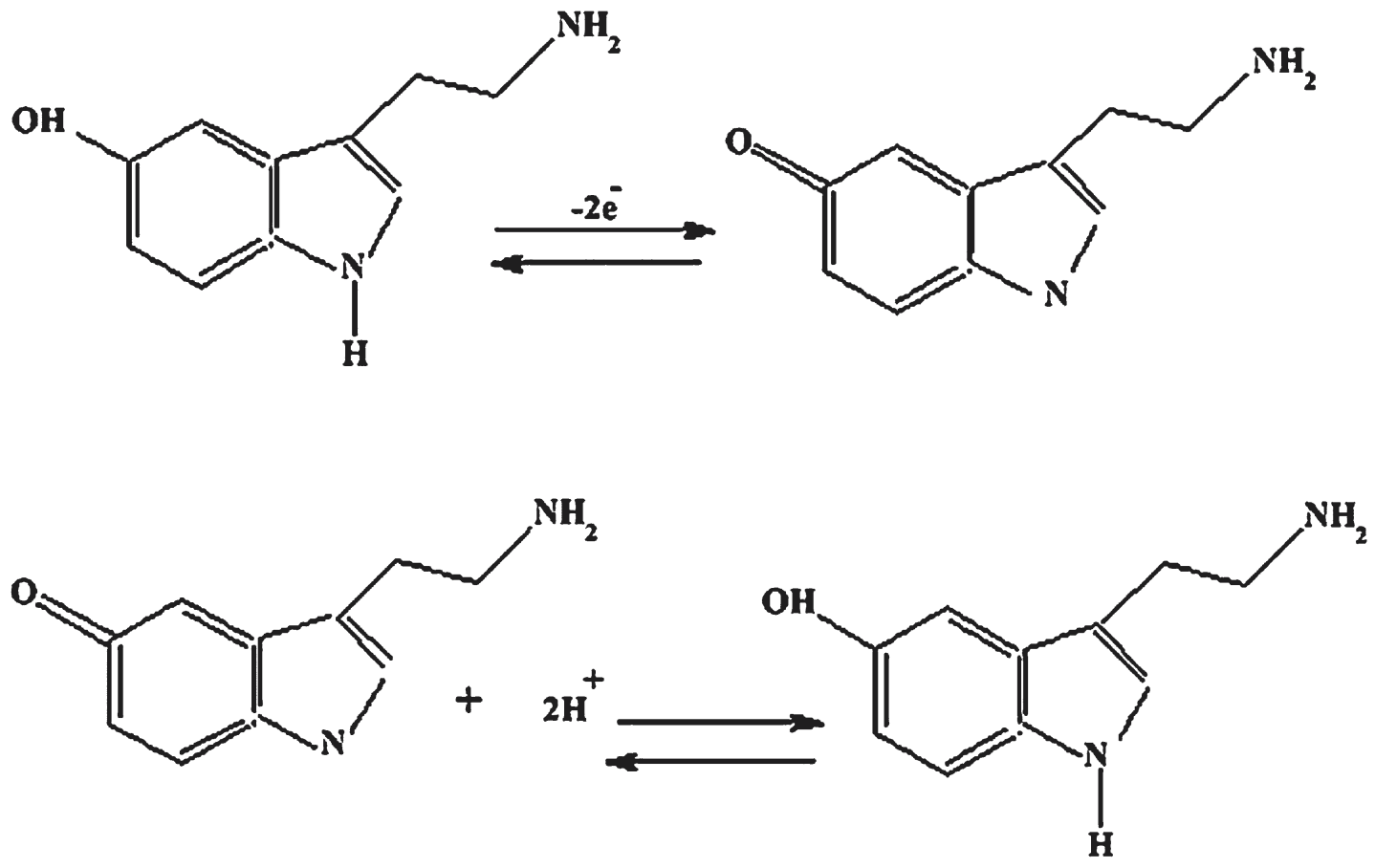

Figure 6: The electrochemical redox reaction of 5-HT on the MIP modified electrode

MIP sensor exhibited a significantly enhanced current response for the detection of 5-HT.

The impedance studies can provide abundant and valuable interfacial properties for electrochemical sensors (Galandova et al., 2008). The EIS was measured on $\mathrm{CPE}, \mathrm{MIP} / \mathrm{CPE}$, and MIP/CPE after the removal of $5-\mathrm{HT}$ in a $\left[\mathrm{Fe}(\mathrm{CN})_{6}^{-3 / 4}\right]$ solution, respectively. The MIP/ $\mathrm{CPE}$ in Figure 4D showed a larger semicircle (curve b) than CPE (curve a) at high frequencies. The results indicated that the MIP film covered the electrode surface and charge transfer resistance $\left(\mathrm{R}_{\mathrm{ct}}\right)$ increased between the $\left[\mathrm{Fe}(\mathrm{CN})_{6}^{-3 /-4}\right]$ solution and the modified electrode. After removing the 5HT template molecules from the MIP membrane, the dense surface of the modified electrode became porous and brittle ( $\mathrm{Li}$ et al., 2015). As a result, facilitated electron transfer between the $\left[\mathrm{Fe}(\mathrm{CN})_{6}^{-3 / 4}\right]$ solution and the modified electrode caused a large decrease of $\mathrm{R}_{\mathrm{ct}}$ (curve c). The results of electrochemical properties of the MIP electrode confirmed the MIP nanocomposite modified metal nanoparticles, which confirmed previous results (Georgescu et al., 2018), an increase in electroactive surface area and peak current, but after removing 5-HT from the MIP matrix, the peak current relatively decreased.

\subsection{Type and $\mathrm{pH}$ of supporting electrolyte}

Several $0.1 \mathrm{M}$ salt solutions including, $\mathrm{KNO}_{3}, \mathrm{LiCl}$, $\mathrm{KCl}$, and $\mathrm{NH}_{4} \mathrm{Cl}$ were tested for a 5 -HT determination as supporting electrolytes by MIP/CPE. According to the obtained results in Figure $\mathbf{5} \mathbf{A}$, the $\mathrm{KNO}_{3}$ solution that has the highest peak currents was selected for further experiments. The effect of $\mathrm{pH}$ was investigated on the electrochemical responses of 5-HT by MIP/CPE by using DPV over the $\mathrm{pH}$ range from $\mathrm{pH} 1.0$ to $\mathrm{pH} 13.0$ in the solution containing $1 \times 10^{-4} \mathrm{M} 5$-HT, and $0.1 \mathrm{M} \mathrm{KNO}_{3}$. The relationship between the current and potential peak of 5-HT on the MIP modified electrode has been shown in Figure 5B. According to Figure 5C, the peak currents increased with an increase in $\mathrm{pH}$ up to $\mathrm{pH} 7.0$, and then suddenly decreased with the subsequent increase of the $\mathrm{pH}$ solution. The idea for this was the role of protons in the electrochemical reaction of 5-HT on the modified electrode (Wang et al., 2015). Therefore, confirming results from $\mathrm{pH} 1.0$ towards $\mathrm{pH} 7.0$ with an increase in the number of protons, peak currents improved, but after $\mathrm{pH}$ 7.0 with a decrease in protons, the peak currents also decreased. Moreover, Figure 5D, shows the linearly dependent potential oxidation peak of 5-HT on $\mathrm{pH}$. The slope of the linear equation is $\mathrm{Ep}=-0.0655 \mathrm{pH}+1.0166$ that is toward $-0.059 \mathrm{~V} / \mathrm{pH}$ base value besides showed equality between the number of electrons transferred and protons (Wu et al., 2003). That suggested the transfer of two electrons and protons were involved in the electrochemical reaction of 5-HT. The possible redox reaction mechanism is depicted in Figure 6. As shown in Figure 6, the role of protons in the electrochemical redox reaction of 5-HT on the MIP modified electrode is also obvious (Koluaçık et al., 2018).

\subsection{The analytical properties of the proposed modified electrode}

The DPV curve in best conditions was employed to detect traces of $5 \mathrm{HT}$ at different concentrations. There is a direct and linear relationship in the concentration range 
Table 1: Electrochemical detection of 5-HT by different methods

\begin{tabular}{|l|l|l|l|}
\hline Method & Detection limit $(\mu \mathbf{M})$ & Linear range $(\mu \mathbf{M})$ & References \\
\hline $\begin{array}{l}\text { Nanocomposite based on graphite, } \\
\text { nanodiamonds and AuNPs }\end{array}$ & 0.1 & 0.3 to 3 & (Ramos et al., 2020) \\
\hline $\begin{array}{l}\text { Molybdenum selenide-reduced graphene } \\
\text { oxide composite }\end{array}$ & $2.5 \times 10^{-3}$ & $1 \times 10^{-2}$ to 1.2 & (Chaudhary et al., 2020) \\
\hline $\begin{array}{l}\text { Carbon nanoparticles functionalize } \\
\text { with sulfonic groups nanocomposite }\end{array}$ & $1 \times 10^{-2}$ & 0.1 to 2 & (Kundys-Siedlecka et al., 2019) \\
\hline $\begin{array}{l}\text { Glassy carbon electrodes based on } \\
\text { carbonnanotube nanocomposite }\end{array}$ & $5.0 \times 10^{-3}$ & $1.0 \times 10^{-7}$ to 1 & (Kim et al., 2011) \\
\hline MIP/CPE & $1 \times 10^{-5}$ & 0.1 to 10 & This work \\
\hline
\end{tabular}
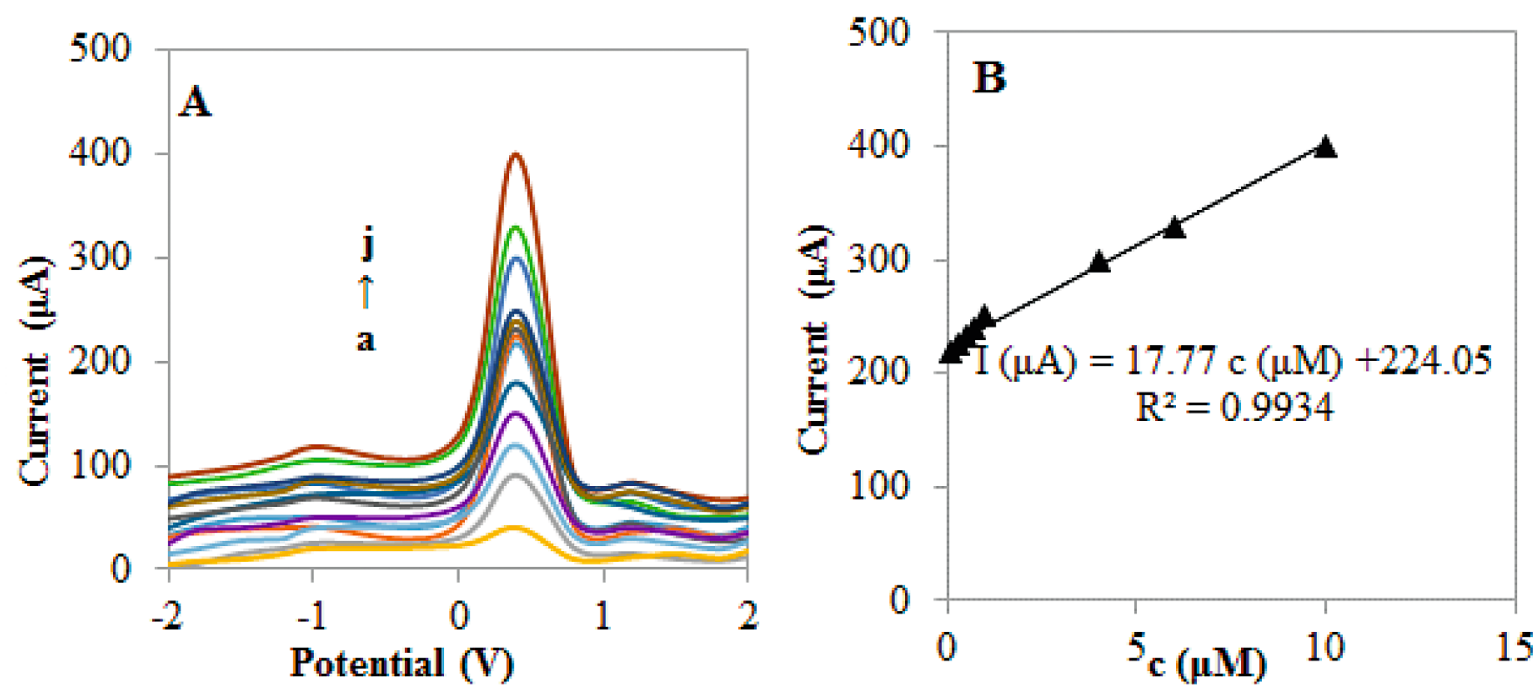

Figure 7: (A) The DPV curves of ${ }_{5} \mathrm{HT}$ on the MIP/CPE electrode in o.1 $\mathrm{M}$ KNO ${ }_{3}\left(\mathrm{pH} 7.0\right.$ ). ${ }_{5} \mathrm{HT}$ concentration (from a to $\mathrm{j}$ curve): $0.01,0.02,0.04,0.06,0.08,0.1,0.3,0.5,0.7,1,4,6,10 \mu \mathrm{M}^{3}$ (B) The linear relationship between the anodic peak currents and the concentrations of 5 -HT (concentration range of 5-HT) was $0.1,0.3,0.5,0.7,1,4,6,10 \mu \mathrm{M}$

of 0.1 to $10 \mu \mathrm{M}$ between the current response and 5-HT concentration with a correlation coefficient of 0.9934 (see Figure 7). According to Table 1, which depicts the obtained results, this concentration range was wider and the detection limit of MIP/CPE was lower than other analytical methods. Consequently, the effect of the nanoparticles in MIP/CPE is better than other modified factors applied in summarized electrodes. After regression analysis, $\mathrm{I}(\mu \mathrm{A})=17.77(\mu \mathrm{M})+224.05$ equation with $1 \times 10^{-5} \mu \mathrm{M}$ detection limit $(\mathrm{S} / \mathrm{N}=3)$ was obtained. It can be seen that this proposed MIP sensor displays a comparable linear range and detection limit for the quantitative determination of 5-HT.

The determination of 5HT was carefully studied by conducting selective experiments using coexisting substances such as ascorbic acid (AA) and uric acid (UA). The DPV responses were recorded for the determination of $6 \mu \mathrm{M} 5$-HT with 10-fold concentrations of (AA) and (UA) by the MIP/CPE, MIP/CPE after removal 5-HT, and CPE, respectively. According to observations, the peak current of 5-HT at the MIP/CPE electrode was much higher than MIP/CPE after the removal of 5-HT,

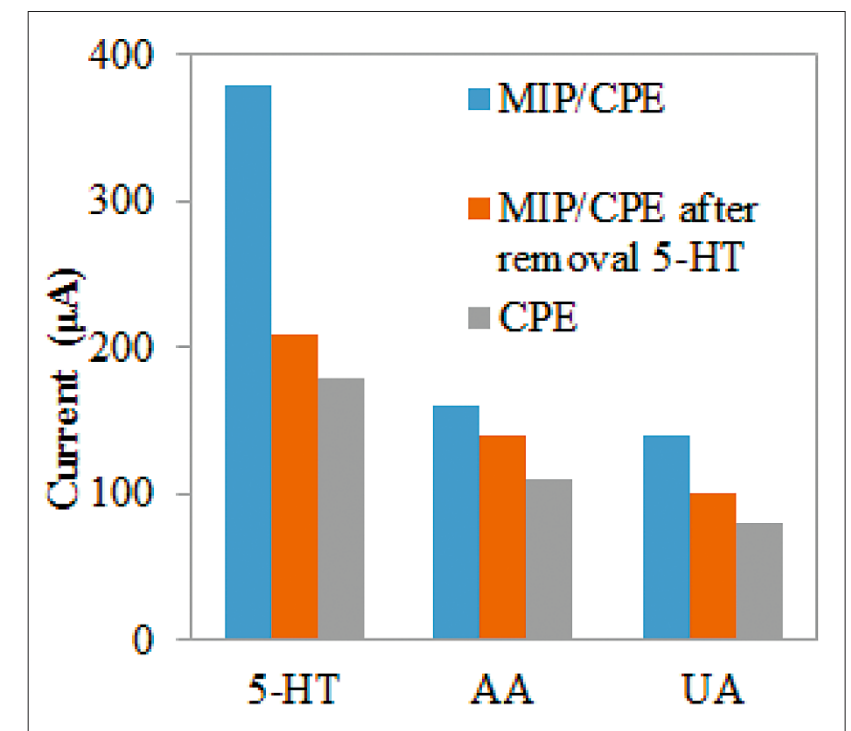

Figure 8: Comparison of the current responses of 5-HT and the structural analogs in $0.1 \mathrm{KNO}_{3}\left(\mathrm{pH}_{7} .0\right)$ at MIP, MIP after removal 5-HT and CPE electrode, respectively (5-HT by MIP/CPE has a high current) 
while CPE had the lowest current (see Figure 8). However, the 100-fold concentration of $\mathrm{Na}^{+}, \mathrm{Mg}^{2+}, \mathrm{Al}^{3+}, \mathrm{NO}$ ${ }^{3-}$, and $\mathrm{SO}_{4}{ }^{2-}$ did not influence the current of 5-HT. Therefore, the current responses of the MIP modified electrode with metal nanoparticles toward 5-HT were much higher than other analogs, indicating a good recognition ability for the template molecules (Wang et al., 2014).

\subsection{Measured 5-HT on real samples}

The analytical application of the electrochemical proposed sensor designed by a metal nanoparticle and polymer matrix is an assessment of 5-HT value in human urine and blood samples. For preparing bio real samples, a mixture of $\mathrm{ZnSO}_{4}-\mathrm{Ba}(\mathrm{OH})_{2}$, and solution acetonitrile was used. After centrifuging, the interfering proteins were deposited. The standard addition method was performed, and the concentrations of 5-HT were detected using DPV and calibration curves. According to Table 2, satisfactory results were obtained with a relative standard deviation (RSD) of 1-3\% and a recovery of 98-102\% (For three repetitions of each concentration analysis, $\mathrm{n}=$ $3)$. Due to the spike and found concentrations in the applicable solution for 5-HT, good RSD was acquired and recovery for 3 repetitions of spike concentration analyses were obtained. These optimal results depend on the standard added volume to an applicable solution that reduced the matrix effect (Zhang et al., 2017). These results indicate that the proposed sensor is precise and reliable. Human urine and blood samples were used because the amount of 5-HT in the neuronal system for the prevention of motivational diseases is vital. All laboratory experiments were performed in agreement with Guidelines IR.IAU.REC and the ethics committee at the Islamic Azad University. All research participants were informed with the aim of the research and fully consented before giving the blood and urine samples.

Table 2: Determination of 5-HT in the real samples by the MIP sensor

\begin{tabular}{|l|l|l|l|l|}
\hline $\begin{array}{l}\text { Samples } \\
(\mathbf{1 0} \boldsymbol{\mu M})\end{array}$ & $\begin{array}{l}\text { Added } \\
(\mathbf{1 0} \boldsymbol{\mu M})\end{array}$ & $\begin{array}{l}\text { Found } \\
(\mathbf{1 0} \boldsymbol{\mu M})\end{array}$ & $\begin{array}{l}\text { Recovery } \\
(\mathbf{\%})\end{array}$ & RSD (\%) \\
\hline \multirow{3}{*}{ Urine } & 0.009 & 0.0089 & 98 & 1.37 \\
\cline { 2 - 5 } & 0.0025 & 0.00245 & 98 & 1.57 \\
\cline { 2 - 5 } & 0.0048 & 0.0048 & 98 & 1.35 \\
\hline \multirow{3}{*}{ Blood } & 0.1 & 0.1 & 100 & 1.0 \\
\cline { 2 - 5 } & 3.6 & 3.7 & 102 & 2.1 \\
\cline { 2 - 5 } & 1.6 & 1.584 & 99 & 1.20 \\
\hline
\end{tabular}

\section{Conclusions}

In this work, a new electrochemical platform for electrochemical detection of 5-HT was designed. The electrochemical synthesis of MIP has improved by using $\mathrm{Fe}_{3} \mathrm{O}_{4} \rightarrow \mathrm{GO}_{-} \mathrm{SiO}_{2}$, AuNPs, and PATP. Electric conduction of sensor and electron transfer between the analysis solution and the working electrode were improved by AuNPs. A composite of $\mathrm{Fe}_{3} \mathrm{O}_{4} \rightarrow \mathrm{GO}-\mathrm{SiO}_{2}$ enhanced stability, catalytic activity, surface area and reduced the toxic effects. A polymeric film of MIP was also developed for the selectivity, stability, and diagnosis of the proposed sensor. Moreover, another unique feature of this sensor is the easy preparation of MIP with the simple removal of a template molecule by $\mathrm{CV}$ scans, no need for washing agents. The proposed electrochemical sensor is an accurate electrochemical measurement method based on a combination of metal nanoparticles and a molecularly imprinted polymer composite for which $\mathrm{Fe}_{3} \mathrm{O}_{4}, \mathrm{GO}-\mathrm{SiO}_{2}, \mathrm{AuNPs}$, and PATP were used for MIP synthesis. All these factors provide a new platform for 5-HT in real samples with high recovery and selectivity.

\section{References}

Afzali, M., Mostafavi, A., Shamspur, T. (2020): A novel electrochemical sensor based on magnetic core $\rightarrow$ shell molecularly imprinted nanocomposite $(\mathrm{Fe} 3 \mathrm{O} 4 \rightarrow$ graphene oxide $\rightarrow$ MIP) for sensitive and selective determination of anticancer drug capecitabine. Arabian Journal of Chemistry, 13, 8, 6626-6638. https://doi.org/10.1016/j.arabjc.2020 .06 .018 .

Ahmed, M. A., Abdelbar, N. M., Mohamed, A. A. (2018): Molecular imprinted chitosan-TiO2 nanocomposite for the selective removal of Rose Bengal from wastewater. International Journal of Biological Macromolecules, 107, 10461053. https://doi.org/10.1016/j.ijbiomac.2017.09.082.

Baig, N., Sajid, M., Saleh, T. A. (2019): Recent trends in nanomaterial-modified electrodes for electroanalytical applications. TrAC Trends in Analytical Chemistry, 111, 47-61. https://doi.org/10.1016/j.trac.2018.11.044.

Battistelli, D., Ferreira, D. P., Costa, S., Santulli, C., Fangueiro, R. (2020): Conductive thermoplastic starch (TPS) composite filled with waste iron filings. Emerging Science Journal, 4, 3, 136-147. DOI:10.28991/esj-2020-01218.

Berger, M., Gray, J. A., Roth, B. L. (2009): The expanded biology of serotonin. Annual review of medicine, 2009, 60, 355-366. https://doi.org/10.1146/annurev.med.60.042307. 110802.

Chau, R. M. W., Patel, B. A. (2009): Determination of serotonin, melatonin and metabolites in gastrointestinal tissue using high-performance liquid chromatography with electrochemical detection. Biomedical Chromatography, 23, 2, 175-181. https://doi.org/10.1002/bmc.1100.

Chaudhary, C., Kumar, S., Chandra, R. (2020): Monophasic molybdenum selenide-reduced graphene oxide nanocomposite sheets based immunosensing platform for ultrasensitive serotonin detection. Microchemical Journal, 159, 105344. https://doi.org/10.1016/j.microc.2020.105344.

Chen, J., Yao, B., Li, C., Shi, G. (2013): An improved Hummers method for eco-friendly synthesis of graphene oxide. Carbon, 64, 225-229. https://doi.org/10.1016/j.carbon. 2013.07.055.

Dong, X., Ji, X., Jing, J., Li, M., Li, J., Yang, W. (2010): Synthesis of triangular silver nanoprisms by stepwise reduc- 
tion of sodium borohydride and trisodium citrate. The Journal of Physical Chemistry C, 114, 5, 2070-2074. https://doi.org/10.1021/jp909964k.

El-Maraghy, C. M., El-Borady, O. M., El-Naem, O. A. (2020): Effective Removal of Levofloxacin from Pharmaceutical Wastewater Using Synthesized Zinc Oxid, Graphen Oxid Nanoparticles Compared with their Combination. Scientific Reports, 10, 5914, 1-13. https://doi.org/10.1038/ s41598-020-61742-4.

Galandova, J., Ziyatdinova, G., Labuda, J. (2008): Disposable electrochemical biosensor with multiwalled carbon nanotubes - Chitosan composite layer for the detection of deep DNA damage. Analytical Sciences, 24, 6, 711-716. https:// doi.org/10.2116/analsci.24.711.

Georgescu, B. E., Branger, C., Iordache, T.-V., Iovu, H., Vitrik, O. B., Dyshlyuk, A. V., Sarbu, A., Brisset, H. (2018): Application of unusual on/off electrochemical properties of a molecularly imprinted polymer based on an EDOT-thiophene precursor for the detection of ephedrine. Electrochemistry communications, 94, 45-48 https://doi.org/10. 1016/j.elecom.2018.08.004.

Ghanbari, K., Roushani, M. (2018): A nanohybrid probe based on double recognition of an aptamer MIP grafted onto a MWCNTs-Chit nanocomposite for sensing hepatitis C virus core antigen. Sensors and Actuators B: Chemical, 258, 1066-1071. 10.1016/J.SNB.2017.11.145.

Gholamnejad, J., Azimi, A., Lotfian, R., Kasmaeeyazdi, S.,Tinti, F. (2020): The application of a stockpile stochastic model into long-term open pit mine production scheduling to improve the feed grade for the processing plant Rudarsko-geološko-naftni zbornik(The Mining-GeologyPetroleum Engineering Bulletin), 35, 51, 115-129 DOI: 10.17794/rgn.2020.4.10.

Gilbertson, S. R., Chen, Y. C., Soto, C. A., Yang, Y., Rice, K. C., Cunningham, K. A., Anastasio, N. C. (2018): Synthesis and activity of functionalizable derivatives of the seroto$\operatorname{nin}$ (5-HT) 5-HT2A receptor (5-HT2AR) antagonist M100907. Bioorganic \& Medicinal Chemistry Letters, 28, 8, 1381-1385. https://doi.org/10.1016/j.bmcl.2018.02.058.

He, Q., Liu, J., Liu, X., Li, G., Chen, D., Deng, P., Liang, J. (2019): A promising sensing platform toward dopamine using $\mathrm{MnO} 2$ nanowires/electro-reduced graphene oxide composites. Electrochimica Acta, 296, 683-692. https:// doi.org/10.1016/j.electacta.2018.11.096

Hernández-Mendoza, G. A., Aguirre-Olivas, D., GonzálezGutiérrez, M., Leal, H. J., Qureshi, N., Treviño-Palacios, C. G., Peón, J., De-Miguel, F. F. (2020): Fluorescence of serotonin in the visible spectrum upon multiphotonic photoconversion. Biomedical Optics Express, 11, 3, 14321448. DOI:10.1364/BOE.380412.

Ioniţă, M., Vlăsceanu, G. M., Watzlawek, A. A., Voicu, S. I., Burns, J. S., Iovu, H. (2017): Graphene and functionalized graphene: Extraordinary prospects for nanobiocomposite materials. Compos. Composites Part B: Engineering, 121, 34-57. https://doi.org/10.1016/j.compositesb.2017.03.031.

Karavasilis, M.,Tsakiroglou, C. D. (2019): Synthesis of aqueous suspensions of zero-valent iron nanoparticles (nZVI) from plant extracts: experimental study and numerical modeling. Emerging Science Journal, 3, 36, 344-360. DOI: http://dx.doi.org/10.28991/esj-2019-01197.

Khalifa, M. E., Ali, T. A., Abdallah, A. B. (2020): Molecularly imprinted polymer based GCE for ultra-sensitive voltammetric and potentiometric bio sensing of Topiramate. Analytical Sciences, 37, 7, 955-962. https://doi.org/10.2116/ analsci.20P313.

Kim, S. K., Bae, S. R., Ahmed, M. S., You, J. M., Jeon, S. W. (2011): Selective determination of serotonin on poly (3, 4-ethylenedioxy pyrrole)-single-walled carbon nanotubemodified glassy carbon electrodes. Bulletin of the Korean Chemical Society, 32, 4, 1216-1220. https://doi. org/10.5012/bkcs.2011.32.4.1215.

Koluaçık, E., Karabiberoğlu, Ş. U., Dursun, Z. (2018): Electrochemical Determination of Serotonin Using Pre-treated Multi-walled Carbon Nanotube-polyaniline Composite Electrode. Electroanalysis, 30, 12, 2977-2987. DOI: 10.1002/elan.201800588.

Kong, M., Jin, P., Wei, W., Wang, W., Qin, H., Chen, H., He, J. (2021): Covalent organic frameworks (COF-300-AR) with unique catalytic performance in luminol chemiluminescence for sensitive detection of serotonin. Microchemical Journal, 160, 105650. DOI:10.1016/j.microc.2020.105650.

Kundys-Siedlecka, M., Bączyńska, E., Jönsson-Niedziółka, M. (2019): Electrochemical detection of dopamine and serotonin in the presence of interferences in a rotating droplet system. Analytical Chemistry, 91, 16, 1090810913. https://doi.org/10.1021/acs.analchem.9b02967.

Li, X., Wang, X., Li, L., Duan, H., Luo, C. (2015): Electrochemical sensor based on magnetic graphene oxide $\rightarrow$ gold nanoparticles-molecular imprinted polymers for determination of dibutyl phthalate. Talanta, 131, 354-360. https:// doi.org/10.1016/j.talanta.2014.07.028.

Li, Y., Song, H., Zhang, L., Zuo, P., Ye, B.c., Yao, J.,Chen, W. (2016): Supportless electrochemical sensor based on molecularly imprinted polymer modified nanoporous microrod for determination of dopamine at trace level. Biosensors and Bioelectronics, 78, 308-314. https://doi. org/10.1016/j.bios.2015.11.063.

Lowdon, J. W., Diliën, H., Singla, P., Peeters, M., Cleij, T. J., van Grinsven, B., Eersels, K. (2020): MIPs for commercial application in low-cost sensors and assays-An overview of the current status quo. Sensors and Actuators B: Chemical, 325, 128973. https://doi.org/10.1016/j.snb.2020.128973.

Lu, Z., Goebl, J., Ge, J.,Yin, Y. (2009): Self-assembly and tunable plasmonic property of gold nanoparticles on mercapto-silica microspheres. Journal of Materials Chemistry, 19, 26, 4597-4602. DOI:https://doi.org/10.1039/B903637G.

Murphy, D. G., Daly, E., Schmitz, N., Toal, F., Murphy, K., Curran, S., Erlandsson, K., Eersels, J., Kerwin, R., Ell, P. (2006): Cortical serotonin 5-HT 2A receptor binding and social communication in adults with Asperger's syndrome: an in vivo SPECT study. The American Journal of Psychiatry, 163, 5, 934-936. https://doi.org/10.1176/ajp.2006 163.5.934.

Parnianchi, F., Nazari, M., Maleki, J., Mohebi, M. (2018): Combination of graphene and graphene oxide with metal and metal oxide nanoparticles in fabrication of electrochemical 
enzymatic biosensors. International Nano Letters, 8, 229239. https://doi.org/10.1007/s40089-018-0253-3.

Peeters, M., Troost, F.J., Van Grinsven, B., Horemans, F., Alenus, J., Murib, M.S., Keszthelyi, D., Ethirajan, A., Thoelen, R.,Cleij, T.J., Wanger, P. (2012): MIP-based biomimetic sensor for the electronic detection of serotonin in human blood plasma. Sensors and Actuators B: Chemical, 171172, 602-610. https://doi.org/10.1016/j.snb.2012.05.040.

Qian, L., Thiruppathi, A. R., Elmahdy, R., van der Zalm, J., Chen, A. (2020): Graphene-oxide-based electrochemical sensors for the sensitive detection of pharmaceutical drug naproxen. Sensors, 20, 5, 1252. https://doi.org/10.3390/ s20051252.

Ramos, M. M. V., Carvalho, J. H.S., de Oliveira, P. R.,Janegitz, B. C. (2020): Determination of serotonin by using a thin film containing graphite, nanodiamonds and gold nanoparticles anchored in casein. Measurement, 149, 106979. https://doi.org/10.1016/j.measurement.2019.106979.

Roychoudhury, A., Francis, K. A., Patel, J., Jha, S. K., Basu, S. (2020): A decoupler-free simple paper microchip capillary electrophoresis device for simultaneous detection of dopamine, epinephrine and serotonin. Royal Society of Chemistry, 10, 56, 25487-25495. DOI: 10.1039/D0RA03526B.

Santos, W. d. J. R., Lima, P. R., Tarley, C. R. T., Höehr, N. F., Kubota, L. T. (2009): Synthesis and application of a peroxidase-like molecularly imprinted polymer based on hemin for selective determination of serotonin in blood serum. Analytical Chimica Acta, 631, 2, 170-176. https://doi. org/10.1016/j.aca.2008.10.034.

Sharma, G., Kandasubramanian, B. (2020): Molecularly imprinted polymers for selective recognition and extraction of heavy metal ions and toxic dyes. Journal of Chemical \& Engineering Data, 65, 2, 396-418. https://doi.org/10.1021/ acs.jced.9b00953.

Smith, A. T., LaChance, A. M., Zeng, S., Liu, B., Sun, L. (2019): Synthesis, properties, and applications of graphene oxide/reduced graphene oxide and their nanocomposites. Nano Materials Science, 1, 1, 31-47. https://doi.org/10. 1016/j.nanoms.2019.02.004.

Torri, C., Reinikainen, M., Lindfors, C., Fabbri, D., Oasmaa, A., Kuoppala, E. (2010): Investigation on catalytic pyrolysis of pine sawdust: Catalyst screening by Py-GC-MIPAED. Journal of Analytical and Applied Pyrolysis, 88, 1, 7-13. https://doi.org/10.1016/j.jaap.2010.02.005.

Volpi-Abadie, J., Kaye, A. M., Kaye, A. D. (2013): Serotonin syndrome. Ochsner Journal, 13, 4, 533-540.

Wang, F., Zhu, L., Zhang, J. (2014): Electrochemical sensor for levofloxacin based on molecularly imprinted polypyr- role-graphene-gold nanoparticles modified electrode. Sensors and Actuators B: Chemical, 192, 642-647. https:// doi.org/10.1016/j.snb.2013.11.037.

Wang, Y., Wang, S., Tao, L., Min, Q., Xiang, J., Wang, Q., Xie, J., Yue, Y., Wu, S., Li, X., Ding, H. (2015): A disposable electrochemical sensor for simultaneous determination of norepinephrine and serotonin in rat cerebrospinal fluid based on MWNTs-ZnO/chitosan composites modified screen-printed electrode. Biosensors and Bioelectronics, 65, 31-38. https://doi.org/10.1016/j.bios.2014.09.099.

Wondracek, M. H. P., Jorgetto, A. O., Silva, A. C. P., do Rocio Ivassechen, J., Schneider, J. F., Saeki, M. J., Pedrosa, V. A., Yoshito, W. K., Colauto, F.,Ortiz, W. A. Castro, G.A. (2016): Synthesis of mesoporous silica-coated magnetic nanoparticles modified with 4-amino-3-hydrazino-5-mercapto-1, 2, 4-triazole and its application as $\mathrm{Cu}$ (II) adsorbent from aqueous samples. Applied Surface Science, 367, 533-541. https://doi.org/10.1016/j.apsusc.2016.01.172.

Wu, H., Denna, T. H., Storkersen, J. N., Gerriets, V. A. (2019): Beyond a neurotransmitter: the role of serotonin in inflammation and immunity. Pharmacological Research, 140, 100-114. https://doi.org/10.1016/j.phrs.2018.06.015.

Wu, K., Fei, J., Hu, S. (2003): Simultaneous determination of dopamine and serotonin on a glassy carbon electrode coated with a film of carbon nanotubes. Analytical Biochemistry, 318, 1, 100-106. https://doi.org/10.1016/S0003-2697 (03)00174-X.

Yáñez-Sedeño, P., Campuzano, S., Pingarrón, J. M. (2017): Electrochemical sensors based on magnetic molecularly imprinted polymers: A review. Analytica Chimica Acta, 960, 1-17. https://doi.org/10.1016/j.aca.2017.01.003.

Zhang, L., Dou, X., Kong, W., Liu, C., Han, X., Yang, M. (2017): Assessment of critical points and development of a practical strategy to extend the applicable scope of immunoaffinity column cleanup for aflatoxin detection in medicinal herbs. Journal of Chromatogrphy A, 1483, 56-63. https://doi.org/10.1016/j.chroma.2016.12.079.

Zhao, L., Zeng, B., Zhao, F. .(2014): Electrochemical determination of tartrazine using a molecularly imprinted polymer-multiwalled carbon nanotubes-ionic liquid supported $\mathrm{Pt}$ nanoparticles composite film coated electrode. Electrochimica Acta, 146, 611-617. https://doi.org/10.1016/j.electacta.2014.08.108.

Zhong, T., Guo, Q., Zhu, X., Liu, R.,Huang, S. (2020): Based on Gold Nanoparticles-L-Tyr-Amino Functionalized Mesoporous Materials-Polyphenol Oxidase Modified Biosensor for Detection of Resorcinol. Analytical Sciences, 37, 6, 817-823. https://doi.org/10.2116/analsci.20P288. 


\section{SAŽETAK}

\section{Novi elektrokemijski senzor temeljen na metalnim nanočesticama i molekularno utisnutom nanokompozitnom polimeru s primjenom u biologiji}

Metalne nanočestice zadržane u biopolimernome kompozitu zbog električne vodljivosti poboljšavaju svojstva elektrokemijskih senzora u biomedicini i izučavanju okoliša. Ovdje je prikazan novi molekularni utisnuti kompozitni polimer temeljen na grafenskom oksidu $\left(\mathrm{Fe}_{3} \mathrm{O}_{4} \rightarrow \mathrm{GO}\right)$, modificiranome silicijevim dioksidom $\left(\mathrm{SiO}_{2}\right)$ i nanočesticama zlata (AuNPs), a s ciljem elektrokemijskoga opažanja serotonina (5-hidroksitriptamin, 5-HT). Određeni iznos 5-HT-a utječe na motivaciju i doživljaj okoliša jer se radi o neurotransmiteru središnjega živčanog sustava. Kod odabira nanokompozita, a zbog učinkovitosti, funkcionalni monomer mora biti pažljivo odabran. Stoga je molekularno utisnuti polimer (MUP) generiran uporabom p-aminotiofenola (PATP), funkcionalnoga nanokompozita $\mathrm{Fe}_{3} \mathrm{O}_{4} \rightarrow \mathrm{GO}_{\mathrm{SiO}} \rightarrow \mathrm{AuNPs}$, $\mathrm{u}$ nazočnosti ${ }_{5}$ HT-a kao templatne molekule. Elektrokemijska polimerizacija nanokompozitnoga MIP-a načinjena je uporabom cikličke voltametrije (CV). Elektrokemijska svojstva 5-HT-a izučena su uporabom različitih tehnologija pulsne voltametrije (PV) u njegovoj otopini. Nakon optimizacije mjernih uvjeta i senzora, koncentracija 5-HT-a linearno je mijenjana u rasponu o,1 - $10 \mu \mathrm{M}$, uz granicu opažanja $1 \times 10^{-5} \mu \mathrm{M}(\mathrm{S} / \mathrm{N}=3)$. Širok raspon koncentracije i nizak prag opažanja te korištene metalne nanočestice MUP-a uz odabrani monomer imali su velik utjecaj na svojstva senzora. Nadalje, metalne čestice funkcionalizirane PATP-om povećale su vodljivost i mogućnost opažanja elektrokemijskih senzora na MIP te kvantificiranje sadržaja 5-HT-a u biološkim uzorcima s velikom točnošću.

\section{Ključne riječi:}

elektrokemijski senzor, metalne nanočestice, molekularno utisnuti polimer, p-aminotiofenol

\section{Author's contribution}

Farzaneh Shaker (Ph.D. student of Analytical Chemistry): performed tests, provided the report and wrote the article. Mohammad Taghi Vardini (Assistant Professor, Analytical Chemistry): proposed ideas and advised the research. Moosa Es'haghi (Assistant Professor, Analytical Chemistry): proposed ideas and advised the research. Ebrahim Ghorbani Kalhor (Associate Professor, Analytical Chemistry): proposed ideas and advised the research. 